\title{
Research on how young adults from children's homes and families are dealing with the idea of parenting
}

\author{
M. Rusnáková \\ Katolícka Univerzita v Ružomberku, Ružomberok, Slovakia
}

\begin{abstract}
The authors in the presented paper are dealing with a view of young adults from children's homes and families on parenting. These views point out the main factors that have a direct impact on their understanding of parenting. These factors are: the attachment bond, the socialisation of a child in a children's home and the reason for placing a child in a children's home. This paper provides the results of a survey that investigates the ideas of young adults from children's homes and families about parenting through the means of a quantitative method, with an emphasis on a comparison of these ideas.
\end{abstract}

Key words: young adult, idea, parenting

\section{Introduction}

The family and environment in which a person is situated, forms and affects them. Throughout the whole adolescence, a person learns to be a parent by receiving care from their own parents, and thus naturally familiarise themselves with parenting. The absence of a family and a home can cause ideas about parenting children from children's homes, in both a positive and a negative sense. The aforementioned factors can, and experience shows it to be the case, subsequently result in socio-pathological forms of behaviour, which social workers encounter in practice. Based on the practical experience of professionals working in this field, it is possible to say that to teach parenting skills to clients only during their parenting is not sufficient with regard to the child, whose care is greatly impaired. There is a risk of the so-called trans-generation transmission, which leads to the transfer of certain patterns of behaviour from generation to generation (abuse, neglect, etc.). It is therefore necessary to be familiar with the idea of parenting by children, before they become parents, and so at a time when these ideas become applicable. "The upbringing of young people and their preparation for life should be among the basic tasks of the political, social and cultural life of a developed society, because there is no morally purer contribution of society than an investment in youth. This interest should be above all economic and political objectives" (Dvorská, 2008: 11). Research that draws attention solely on finding out ideas about parenting by young adults from children's homes is currently unknown. For this reason, the authors of this paper decided to conduct research focusing on this issue. The results are presented in the submitted paper. 


\section{Factors affecting parenting by young adults from children's homes}

Adult femalespt and adult males often become parents. Parental instincts are naturally anchored in each individual and they have been present in them even earlier than the partner roles. "Etiology knows that parental behaviour is more primal than partner behaviour" (Matoušek, 1997: 13). The process of preparation for parenthood is influenced by the family and the family environment, or by a substitute family environment, the school environment and the whole society, in which the child grows up. The child takes over certain patterns of behaviour by his parents towards each other and towards him as a child. On the basis of this adopted behaviour, the child in adulthood, as a parent, is largely influenced by his parents. Among children who do not grow up with their family, but have lived in children's home, parental behaviour patterns are absent. Our assertion relies also on the authors, who are quoted by Vágnerová (2008). They claim that the need to start a family is significantly influenced by experiences from childhood, how the adult perceived the potential burden of maternity and the parental role, how their parents coped and what kind of experience they had with their behaviour towards them as their child. The daughters of "bad" mothers feel less confident and successful in a maternal role, or do not accept parenthood at all. If the model of the parents represents a positive role model, the parental role is perceived positively and the person knows how to behave as a parent, without fear that he will fail. Otherwise, if the parental role model was perceived negatively, there is a higher probability of an attitude of rejection towards becoming a parent. On the other hand, an adult person may try to become a parent that they had always wished to have.

Haštopt (2005) also talks about the impact of the parents on their child and his future parenting, when defining pathogenic parental behaviour. A so-called attachment bond arises between the child and the parent. Hašto says that the creation of an attachment bond is being hindered, or is impossible, if the child encounters certain pathogenic behaviour patterns of their parents. It then has implications for the psycho-dynamics of the child, for his interpersonal behaviour, which may lead, in adulthood, to numerous different frustrations and conflicts. In connection to this, the characteristics of high-risk parents are presented, according to Fischer, Škoda (2007), which may lead to the psychological deprivation of a child, to maltreatment and abuse. It concerns parents, who are specific in their behaviour:

- they do not have sufficient competencies for the parental role and are unable, or for various reasons, cannot perform this parental role

- they do not have sufficient motivation to become a parent

- they tend to react violently, they have less ability to control themselves,

- they have different mental and behavioural disorders (personality disorders, psychoses, ...)

- they are individuals who do not ever want a child

- they have a different sexual orientation, and a morally disturbed and sexually immature personality

- they have low levels of self-control and do not manage their impulses.

It is assumed that if a young adult, without the assistance of other person, can take care of himself, maintain social relationships, work and is not dependent economically, then, theoretically, he is prepared for the role of a parent. The study will analyse a theoretical level, because in the process of preparation for parenthood, other factors also play an important role, such as the forgiveness of his parents, the ability and willingness to live in a partnership, the opinion on how to start a family, to raise children, etc. 
According to the research of Mikloško (2011), it is 52 times more likely that mothers and fathers, who have been placed into institutional care in the past, will have their children taken from their care, than parents for whom institutional care was not prescribed. Although during the conducted research questionable issues emerge with respect to its methodology, importance is attributed to it in the context of our paper. There are several possible reasons why the research indicates such a high value. It is therefore very important that the field of social work, in cooperation with other disciplines, such as pedagogy or psychology, underlines the importance of the children's education about parenting in children's homes, as their basic needs, as well as the role models, were absent during their upbringing. In the following part of this paper, selected factors affecting parenting by young adults from children's homes are presented, emphasising those areas on which it is necessary to focus on during the upbringing towards parenthood.

\section{$>$ The reason for the removal of a child from their biological family}

A child usually grows up in a children's home, because he does not have a person in his family who could take care of him and someone who could fulfil his basic needs. Mikloško (2011) points out that the most common causes for placing a child into institutional care are: the neglect of the child, a loss of housing, alcoholism of the father, alcoholism of the mother, an inability to manage the health condition of a child and the loss of employment, as well as other reasons. The trauma, which the neglected child has experienced, negatively affects him, which may be reflected in different areas of his life, in a different time-frame.

\section{$>$ Socialisation in a children's home}

It is evident that the environment of a children's home cannot fully replace the upbringing in a family. Papšo (2011: 34) rightly concludes that: "the purpose of education and socialisation is to prepare a child or a young person to enter the life itself in adulthood and secure him favourable conditions for his successful social adaptation". The question remains whether the children's home environment can prepare an individual for parenthood, marriage and life itself. If a child, during his life in a children's home, does not perceive in his environment the role model and patterns of a father and a mother, the working habits of his parents, the relationship of the father towards the mother and vice versa, sibling relationships, financial management in the household and so on, it is difficult to talk about a healthy socialisation, which prepares individuals towards parenthood and the life outside of the children's home.

\section{$>$ Fulfilling the needs of children in children's home}

The needs of every child are divided into three main categories, into which the following needs should be included. These needs are influencing each other. Without satisfaction of all these needs, a child cannot gain a socially mature and independent personality, which is sufficiently prepared for parenthood. The lack of fulfilment of these essential needs during adolescence can lead to serious social problems in adulthood. Meeting the needs of the child can be likened to a wheel. A wheel consists of three arms (needs), if one of these needs breaks, the wheel shall no longer be able to roll. Biological needs (food and drink, accommodation, heat, health care, etc.) are fulfilled by the children's home. A children's home provides, according to the Act of the National Council of the Slovak Republic No. 305/2005 Coll. on Social Legal Child Protection and Social Guardianship, a securing of the continuous protection of life, health and the favourable psychological, physical and social development of 
the child. Psychosocial needs (family, home, unconditional acceptance, importance, uniqueness, independence, self-realisation, love, hugs, praise, punishment, attention, privacy, commitment, discussions, safety, protection, security, belonging and identity) are partially fulfilled by the children's home. However, it cannot fully replace the family. This means that the psychosocial needs of a child are not naturally and fully fulfilled. Therefore, children's homes are constantly seeking to place children into substitute families, professional families, etc. Material needs, which are not necessary for human life, nor for the social life of a person, but fulfil the function associated with the natural human characteristic of a desire to own something (the ownership of personal material things such as, for example, toys, a laptop, a cell phone, a car, one's own housing, designer clothes, cosmetics, etc.). The children's home cannot meet the material requirements of every child for financial reasons, when compared to the average Slovak family.

\section{$>$ Attachment person}

Professionals, who are devoted to the idea of an attachment bond, express the conviction that an essential need of every child is to have an attachment person by their side. Among children from children's homes, the fulfilment of the need for an attachment bond is much more complicated, compared to a child who grows up in a healthy family environment and considers a parent as his attachment person. However, in the case of children from children's homes, there are no parents who are actually raising them. An attachment person is understood to be a person who unconditionally accepts and loves a child, and thus the child has an irreplaceable feeling of safety and security. Without doubt, the absence of such a person, negatively affects the child in the future. The individual often tends to have a problem with establishing social relationships, which causes the inability to find a suitable life partner. Papšo (2011) in his research investigated the relationships of young adults from children's homes and the reasons of their termination. He found that during the examined period $61.17 \%$ of young adults did not have a partner relationship, although they were in a relationship in the past. $22.33 \%$ of young adults found themselves in a relationship, $8.74 \%$ of young adults lived a married life. Furthermore, $7.77 \%$ of young adults did not have, and have never been in a partner relationship. He also investigated the number of relationships. $61 \%$ of men and $53.68 \%$ of women have had more than 5 partners. While up to $76.84 \%$ of the young adults, stated that they do not know the reason for the termination of the partner relationship, which they have had. Indeed, Papšo did not unequivocally claim that the identified data is affected by the absence of an attachment bond, equally just as it is not possible to confirm this neither can it be unequivocally dismissed.

\section{$>$ Social integration into society after leaving the children's home}

In the family, parents are predominantly helping their already adult child to become independent. Parents support the young adult towards being educated and employed, to secure housing and so on. This process does not take place in a short time and is not easy. The family provides a young adult with certainty and safety, the so-called nest, where he can return in the event of any unplanned incurred problems. Rusnáková (2008) says that a child coming from a functional family is emotionally stable, trusts the parents, and has positive relationship towards society. Since a young adult from a children's home does not have contact with his parents, or maintains limited contact with them, he is compelled to use substitute assistance or support (e.g. from the State or other facilities, organisations, partners, etc.). This substitute support or assistance is in 
most cases temporary in nature and fails to fully replace the so-called nest, which has been mentioned. For the planned establishment of a family, at least a minimum financial stability is necessary, which is considered to be suitable housing and a job. Therefore, the social integration of young adults into society, after leaving the children's home, is considered to greatly affect parenting in the future.

\section{$>$ Home}

The home is generally a place, where a person grew up and where he has the opportunity to return, in the case where he is in an unfavourable living situation and needs the support of his family. The absence of this feeling causes psychological problems (for example in the form of anxiety disorders or excessive fear), that after leaving the children's home they will become homeless. From the life experiences of former children from children's homes, they often say how much they missed their own separate childhood room in the children's home.

\section{Theoretical and methodological starting points for research}

The research has the character of quantitative research, and the questionnaire method has been chosen as the method of data collection. The questionnaire method has been chosen primarily for the reason of the difficulty of accessibility towards the respondents of the research sample.

\section{The subject, object and objective of the research}

- The subject is the idea of parenting by young adults from children's homes.

- The object consists of young adults from children's homes, young women and men who live in a children's home for different period of time and who are within the age range, as characterised by the National Council of the Slovak Republic Act No. 305/2005 Coll., i.e. from 18 to 25 years of age.

- The objective is to investigate the idea of parenting by young adults from children's homes.

\section{Characteristics of the research sample}

The research sample, which was formed by young adults from children's homes, consisted of 48 respondents (19 women and 29 men). The average age of the women was 19.73 years of age, and of the men, 19.55. A control sample of the respondents, which serves as a comparison of the selected research findings, made up of young adults from complete families, consisted of the same number of 48 respondents (19 women and 29 men). The average age of the women was 20.94 years of age and 21.19 years among the men.

\section{Characteristics (criteria) of the research sample:}

$>$ young adults from 18 to 25 years of age

$>$ a student

$>$ currently placed in a children's home.

\section{Characteristics (criteria) of the control sample:}

$>$ young adults from 18 to 25 years of age

$>$ a student

$>$ permanent residence with parents

$>$ in the purpose of the research, a complete family is considered to be life in a family with one's own living father and one's own living mother. 
Table 1. Hypotheses and research questions.

\begin{tabular}{|c|c|c|}
\hline Category & H / RQ & $\begin{array}{l}\text { The wording of the hypotheses / research } \\
\text { questions }\end{array}$ \\
\hline \multirow{3}{*}{ The idea of a child } & $\mathrm{H} 1$ & $\begin{array}{l}\text { It was assumed that the idea of a child by young } \\
\text { adults from complete families is more positive than } \\
\text { in young adults from children's homes. }\end{array}$ \\
\hline & RQ1 & $\begin{array}{l}\text { Is there a relationship between the idea of a child by } \\
\text { young adults from children's homes and the length } \\
\text { of time spent in the children's home? }\end{array}$ \\
\hline & RQ2 & $\begin{array}{l}\text { Is there a relationship between the idea of a child } \\
\text { by young adults from children's homes and the } \\
\text { relationship towards their mother? }\end{array}$ \\
\hline \multirow[t]{2}{*}{$\begin{array}{l}\text { Concerns associated with the idea } \\
\text { of parenting }\end{array}$} & $\mathrm{H} 2$ & $\begin{array}{l}\text { It was assumed that young adults from children's } \\
\text { homes considered housing to be the greatest } \\
\text { concern with regards to the idea of parenting. }\end{array}$ \\
\hline & RQ3 & $\begin{array}{l}\text { What do young adults fear most in relation to the } \\
\text { idea of their future role as parents? }\end{array}$ \\
\hline \multirow[t]{2}{*}{$\begin{array}{l}\text { Parenting skills } \\
\text { and qualities }\end{array}$} & $\mathrm{H} 3$ & $\begin{array}{l}\text { It was assumed that young adults from complete } \\
\text { families have more developed parenting skills and } \\
\text { qualities than young adults from children's homes. }\end{array}$ \\
\hline & RQ4 & $\begin{array}{l}\text { Does there exist a relationship between the } \\
\text { parenting skills of young adults and the qualities } \\
\text { and length of time spent in a children's home? }\end{array}$ \\
\hline \multirow{4}{*}{ The promiscuity of young adults } & $\mathrm{H} 4$ & $\begin{array}{l}\text { It was assumed that more than } 50 \% \text { of young adults } \\
\text { have experienced more than } 4 \text { relationships. }\end{array}$ \\
\hline & RQ5 & $\begin{array}{l}\text { Have young adults from children's homes had } \\
\text { more relationships than young adults from complete } \\
\text { families? }\end{array}$ \\
\hline & RQ6 & $\begin{array}{l}\text { Does the idea of young adults from children's } \\
\text { homes about fidelity in a relationship differ from } \\
\text { young adults from complete families? }\end{array}$ \\
\hline & RQ7 & $\begin{array}{l}\text { Is there a relationship between the idea of fidelity } \\
\text { in a relationship and the current marital status of } \\
\text { young adults from children's homes? }\end{array}$ \\
\hline
\end{tabular}

$\mathrm{H}=$ Hypothesis, $\mathrm{RQ}=$ Research Question.

\section{Research Question (RQ) and Hypotheses (H)}

Variables were identified when determining the hypotheses and research questions. Independent variables are demographic characteristics (sex, age), the length of time spent in a children's home and the relationship towards the parents. The dependent variable is the idea of parenting, which consists of: the idea of a child, concerns regarding the idea of parenting, parenting skills and qualities, the concept of fidelity in a relationship - promiscuity. The main research question (RQ) emanates from the objective: What is the idea of parenting by young adults from children's homes?

\section{Verification of the hypotheses and research questions}

H1 It was assumed that the idea of a child by young adults from complete families is more positive than among young adults from children's homes.

The formulation of the hypothesis was based on the three-dimensional theory of interpersonal behaviour, by W. C. Schutz. He talks about negative experiences in childhood, which lead towards deficient or pathological behaviour. The subject of the investigation of this hypothesis has been chosen for the following reason. The three-dimensional theory of interpersonal behaviour by W. C. Schutz (Nohejl, 2001) is concerned with the important 
role that the environment in which a person lived plays in shaping his personality. Schutz very specifically defines the influence of the experience from childhood on the type of behaviour in adulthood. According to the relationship between the parents and the child, either satisfaction or dissatisfaction of interpersonal needs occurs. The negative experiences, which an individual experiences in childhood, lead towards deficient and excessive behaviour, or towards pathological behaviour. If the child is loved in childhood and has positive feedback himself, his behaviour is ideal, according to Schutz's classification of fulfilling the satisfaction of interpersonal relationships. For the purpose of our work, the removal of the child from his biological family and the placing of him into a children's home, is considered as a negative experience in childhood. According to the aforementioned theory, a person who experienced negative experiences in childhood and has experienced a traumatic event, which in our work is understood to be the removal from the biological family, should account for undesirable behaviour, which may also lead to negative ideas about a child. The research findings from young adults in children's homes are subsequently compared to the findings of the control sample, which consisted of young adults from complete families. The criterion of a verification of the hypotheses was the difference of the arithmetic mean of the category modes of more than 1.0.

$>$ the hypothesis was not confirmed.

Through the research, it was found that the idea of young adults about a child from complete families is not more positive than the idea of young adults about a child from children's homes. The main findings were as follows: mode $\mathrm{V} 5=3$, mode $\mathrm{V} 10=2$, mode $\mathrm{V} 1, \mathrm{~V} 2, \mathrm{~V} 3, \mathrm{~V} 4, \mathrm{~V} 6, \mathrm{~V} 7, \mathrm{~V} 8, \mathrm{~V} 9=1$. The arithmetic mean of the modes is 1.3 . In young adults coming from complete families, the mode V1, V2, V3, V5, V8, V10 = 2, the mode V4, $\mathrm{V} 6, \mathrm{~V} 7, \mathrm{~V} 9=1$. The arithmetic mean of the modes is 1.6. From a comparison of the results, it follows that with a difference of 0.3 , the idea of a child by young adults from children's homes is actually more positive than in young adults from complete families. The theory, on the basis of which the hypothesis was presented, has proved to be false.

$R Q 1$ Is there a relationship between the idea of a child by young adults from children's homes and the length of time spent in the children's home?

$>$ zero correlation.

The detected correlations of the individual dicta were thus interpreted: $\mathrm{V} 2=$ a negative correlation, $\mathrm{V} 1, \mathrm{~V} 10=$ zero correlation, V3, V4, V5, V6, V7, V8, V9 = a positive correlation. The arithmetic average of the correlations indicates a correlation of the whole category of the "idea of a child" and the length of time spent in a children's home, which is a value of 0.49. This concerns a correlation on the edge between zero and a positive correlation, where the border of zero correlation with the positive correlation is precisely our value of 0.49 . There is no connection, or very little connection, between the idea of a child by young adults from children's homes and the length of time spent in a children's home.

$R Q 2$ Is there a relationship between the idea of a child by young adults from children's homes and the relationship towards their mother?

$>$ zero correlation.

The correlations of the first category "the idea of the child": V1, V10 = a negative correlation, V9 = zero correlation, V2, V3, V4, V5, V6, V7, V8 = a positive correlation. Even though similar to RQ1, the positive correlation, by their number, markedly outweigh in excess of the zero and negative ones, the arithmetic mean represents a correlation of 0.44 , which is a zero correlation. In our conducted research, it was found that there is no relationship between the idea of a child and the relationship towards the mother of young adults from children's homes, or it exists, but there is a very small relationship. 
H2 It was assumed that young adults from children's homes consider housing as the highest concern in relation to the idea of parenting.

The formulation of the hypothesis was based on research conducted in 2009. Žarnay found that young boys from children's homes considered housing as the greatest concern, and that young boys from a functional family were mainly concerned about finances.

$>$ The hypothesis was not confirmed.

$>$ Young adults from both children's homes and complete families considered financial problems to be the greatest concern.

The young adults from children's homes (46.27\%) and the young adults from complete families (33.33\%) are mostly concerned about financial problems. The second major concern for young adults from children's homes, in $11.94 \%$ of cases, is that they will be like their mother/father. Among young adults from complete families, the concern about raising a child actually came second. It is interesting to note that $1.48 \%$ of young adults from children's homes are concerned that they do not have anyone who will help them, while young adults from complete families, at $4.17 \%$, are actually more concerned by this worry. The biggest difference in the responses among young adults from children's homes and complete families was with concerns about commitment and responsibility. The smallest difference was with concerns about a lack of time for their interests.

$R Q 3$ What do young adults fear most in relation to the idea of their future role as parents?

$>$ Young adults from children's homes, regarding the idea of their future role as parents, are most concerned about independent living and independence, while young adults from complete families are most concerned about work.

The respondents were asked about 5 areas, where they marked whether it is an area that they fear or one that they look forward to. It was found that in $54 \%$ of cases, young adults from children's homes considered independent living and independence as the greatest concern. This was further followed by a concern about children, $38 \%$, work $32 \%$, their own household, $30 \%$ and marriage, $28 \%$. Young adults from complete families are most concerned about work (29\%), followed by concern about marriage (25\%), children (23\%), their own household (21\%) and independent life and independence (19\%). By merging the findings from $\mathrm{H} 2$ and RQ3, the areas of concern in young adults from children's homes are understood to be - an independent life and independence, in relation to the fear of financial problems. In young adults from complete families, the areas of concerns are understood to be - work in connection with financial problems.

H3 It was assumed that young adults from complete families have more developed parenting skills and qualities than young adults from children's homes.

The hypothesis was determined based on the knowledge of sociology. It was assumed that since young adults in children's homes do not have a positive parental role model, they would have less developed parenting skills and qualities than young adults from complete families. The second fact from which the formulation of the hypothesis emanated was the discovered fact that among mothers of former children from children's homes, it is 52 times more likely that the child will be taken from them; at the same time it is also more likely in fathers who were ordered into an institutional upbringing in the past. Therefore, of primary interest is whether or not the quality of parenting skills and the qualities of young adults from children's homes differ from the parenting skills and qualities of young adults from complete families. This category, which deals with the investigation of parenting skills and qualities, is conditional on the self-assessment or the self-esteem of the respondents. 
$>$ the hypothesis was not confirmed.

Young adults from complete families do not have more developed parenting skills and qualities than young adults from children's homes. With the skills and qualities of young adults from children's homes, parental skills/qualities is No. 1,2,4,5,7,8,9 mode $=1$, No. 3,6 mode $=2$. Young adults from children's homes consider the most developed skills/qualities to be fairness and independence. This finding is quite interesting, because in RQ3 it was found that most young adults from children's homes consider independent life and independence to be a concern. Most young adults from complete families (58.33\%) identified that they solve problems with discretion and in a calm way. All skills/qualities mode $=2$, with the fact that No. 4 mode $=1.2$. The arithmetic average of the modes among young adults from children's homes is 1.22, and among young adults from complete families, is 1.90. It follows that, despite the fact that young adults from children's homes do not grow up in a natural family environment, they do not show significant differences compared to young adults who grew up in complete families. On the contrary, it was found that young adults from children's homes have more developed parenting skills and qualities, compared to young adults from complete families.

$R Q 4$ Is there a relationship between the parenting skills of young adults and the length of time spent in a children's home?

The relationship between parental skills and qualities and the length of time spent in a children's home was examined. It was discovered that the average length of time spent in a children's home by our respondents is 11.12 years, the mode $=16$.

$>$ positive correlation.

It has been shown that 8 from 9 of our examined parenting skills and characteristics are positively correlated. A zero correlation of 0.30 was for the dictum "I know how to cook". The most correlated length of time spent in a children's home with the dictum "I know how to sensibly manage money", 0.89 , this is followed by "I am fair", 0.87 , "I solve problems calmly and wisely", 0.81, "I am independent", 0.79, "I am reliable", 0.78, "I know how to adapt quickly" and "I am patient", 0.76 , and the smallest, but still a strong correlation of 0.75 , "I am adept in the solution of official matters".

H4 It was assumed that more than 50\% of young adults have experienced more than 4 relationships.

The formulation of the hypothesis was based on the research of Papšo (2011). His research sample consisted of 103 young adults, who grew up in children's homes. He discovered that $12.64 \%$ of young adults have had 4 relationships, $25.26 \%$ have had 5 relationships in the past and $53.68 \%$ of young adults have had more than 5 relationships.

$>$ the hypothesis was not confirmed.

It was found that $57.89 \%$ of young women from children's homes have experienced more than 4 relationships, $26.31 \%$ less than 3 relationships and $15.80 \%$ have never been in a relationship. $34.49 \%$ of young adult men from children's homes have experienced more than 4 relationships, the largest percentage of 58.62 was less than 3 relationships, and $6.89 \%$ have not been in a relationship. On average, young adults from children's homes experienced less than 3 relationships (45.83\%), followed by more than 4 times, $43.75 \% .10 .42 \%$ of young adults from children's homes were not in a relationship.

$R Q 5$ Have young adults from children's homes had more partner relationships than young adults from complete families?

The results from the verification of $\mathrm{H} 2$ were compared with young adults from complete families. The number of relationships experienced by young adults from children's homes and complete families was of particular interest. 
> Young adults from children's homes had 4.19 times more relationships than young adults from complete families.

As mentioned in $\mathrm{H} 2,45.83 \%$ of young adults from children's homes had less than 3 relationships, $43.75 \%$ had more than four relationships and $10.42 \%$ had not been in a relationship. $77.08 \%$ of young adults from complete families have been in a relationship less than 3 times, $10.42 \%$ more than 4 times, and $12.50 \%$ have not been in a relationship. In order to respond to RQ5, the discovered data in the option "More than 4 times" among young adults from children's homes and from complete families was then compared. There are 4.19 times more young adults from children's homes who have been in a relationship more than 4 times, than young adults from complete families.

RQ6 Does the idea about fidelity in a relationship by young adults from children's homes differ to young adults from complete families?

An essential condition for the very existence of parenthood is a partner. In the conditions of Slovak society, in the context of religion, culture and history itself, the preferred lifelong relationship with the mother/father of their child is within a marriage. The idea of whether or not fidelity in the relationships of young adults in children's homes differs from the idea of fidelity in the relationships of young adults from complete families was of primary interest.

$>$ the idea of fidelity in the relationships of young adults from children's homes differs from the ideas of the relationships of young adults from complete families by at least $2.5 \%$.

In reply to RQ7, the answers "I agree" and "I somewhat agree" were counted, as a percentage. The responses "I do not know" were not counted. Concerning fidelity in a relationship, $210.0 \%$ (from $300 \%$ ) of young adults from children's homes and $212.5 \%$ (from $300 \%$ ) of young adults from complete families, prefer marriage and fidelity in relationships more than alternating partners.

$R Q 7$ Is there a relationship between the idea of fidelity in a relationship and the current marital status of young adults from children's homes?

$>$ zero correlation.

In order to answer RQ8, the number of respondents currently found in a relationship was first investigated. In the period of the research, $47.92 \%$ of the respondents were in a relationship, i.e. had a boyfriend/girlfriend and $52.08 \%$ were not in a relationship. Three dicta were also investigated for the answer to RQ8. The dictum "I prefer alternating partners before marriage" is correlated to the level of 0.71 , thus there is a strong correlation. Conversely, the dicta "I believe in the strength of marriage" and "I will be faithful to the father/mother of my children forever" show a strong negative correlation. The arithmetic average of the correlation is -0.27 and thus a zero correlation for the ideas of fidelity in a relationship and the current marital status of young adults from children's homes.

\section{Conclusion}

In conclusion of this work, those research findings of the available studies, which were also examined, are presented, through which are the following updated findings:

$>$ Rabušic (in Vágnerová, 2008), in his research, discovered a shift in the views of young people on the value of a child. He found out that young people no longer consider a child as a necessary condition for the fulfilment of life. 
The dictum "I consider a child to be a necessary condition for the fulfilment of my life." was verified in both the examined groups of respondents, surveyed through scalability questions. Subsequently, the responses I agree and I somewhat agree, and the responses I disagree and I somewhat disagree were added up. The response I do not know was not added up. It was found that $62.5 \%$ of young adults from children's homes deemed a child to be a necessary condition for the fulfilment of their lives. $25 \%$ of respondents disagreed with the statement. The findings were very similar to young adults from complete families. $64.58 \%$ consider the child as a necessary condition for the fulfilment of their lives, $16.66 \%$ do not. Based on our findings, it can be concluded that the research findings of Rabušic, from 2000, are no longer current. An average of $63.54 \%$ of young adults from children's homes and complete families considered the child as a necessary condition for the fulfilment of their lives.

> Hamplová (in Vágnerová, 2008), in her research, found out that 30\% of young people have agreed with the assertions: "The child represents too great a restriction on freedom." and at the same time "For the parents, the greatest joy is that they can watch their child grow".

From the examined dicta, the responses "I agree" and "I somewhat agree" were added up and it was discovered that the child constitutes too big a restriction on the freedom of $27.09 \%$ of young adults from children's homes and for $24.99 \%$ of young adults from complete families. Based on our findings, it was concluded that the research findings of Hamplová, from 2000, do not differ significantly, on average $26.04 \%$ of young adults considered the child as a restriction of freedom. $87.5 \%$ of young adults from children's homes and $89.58 \%$ of young adults from complete families, agreed with the dictum that for a parent the greatest joy is to see their child grow up. An average of $57.81 \%$ of young adults agree with the assertion that for a parent the greatest joy is when you can see your child grow, which is a marked difference from the research findings of Hamplová.

> Žarnay (2009) discovered that young boys from children's homes are most concerned about housing and young boys from functional families are most concerned about finances.

In our conducted research, the concerns of young men and women were investigated. It was discovered from the conducted research that both research samples of respondents considered the greatest concern to be finances, in connection with the idea of parenting (an average of $40 \%$ ). More specific concerns were also investigated and it was found that financial concerns for young adults from children's homes are associated with independent living and independence (54\%) and with work for young adults from complete families (30\%). It is interesting to note that concern about an independent life and independence was classified as the greatest concern for young adults from children's homes and as the smallest concern in young adults from complete families.

$>$ Papšo (2011) found that $91.58 \%$ of young adults had more than 4 relationships. Papšo examined 103 young adults, who lived in children's homes.

In our conducted research, approximately half the number of the respondents were examined compared to Papšo's research. It was discovered that $43.75 \%$ of young adults had more than 4 relationships, which is less than half compared to Papšo's resulting data research. The distinctive difference can be attributed to the average age of the respondents, which was 23.28 years in Papšo's research and 19.64 years in ours. Thus it can be concluded that the number of relationships proportionally grows with the increasing age of young adults. This 
conclusion is, however, questionable. Summing up the responses "I agree" and "I somewhat agree", it was found that $64.58 \%$ of respondents believe in the strength of marriage, $75 \%$ of respondents do not prefer an alternation of partners before marriage and $70.83 \%$ of respondents plan to be faithful to the father/mother of their children.

> Vágnerová (2008) states the research findings of a number of authors from 2000-2003. They state that the most optimal age for the procreation of the first child is 24.5 among women and 28 among men.

In our research, statistical information about the growing age of first-time mothers can be confirmed, because it was found that respondents considered the most optimal age for the procreation of the first child to be from 26 to 30 years. They themselves want to become parents between the ages of 26 to 30 .

It is also worth mentioning the new findings or findings that require enlightenment, which was found out in the scientific research and which has been analysed within the empirical part of the work:

- young adults from children's homes consider a sibling as the closest person, followed by a friend and a social worker,

- the least amount of young adults from complete families consider the father as the closest person, while before the father, young adults from complete families, prefer a sibling, a friend, boyfriend/girlfriend and the mother,

- the idea of a child for young adults from complete families is worse than the idea of a child for young adults from children's homes,

- in seven out of ten dicta from the category of the "idea of a child", a positive correlation to the relationship of the respondents towards their mother was indicated,

- in seven out of ten dicta from the category of the "idea of a child", a positive correlation to the length of time spent in a children home was indicated,

- the idea of fidelity in a relationship is more positive for young adults from complete families,

- young adults from children's homes consider independence as their most developed quality, while at the same time, especially independent life and independence are stated as their greatest concerns,

- there is a relationship between developing parenting skills and qualities and the length of time spent in a children's home; and there is no relationship between the idea about fidelity in a relationship and whether the young adult is currently in a relationship.

In the social integration process of the children into society, once they have left the children's home, the social worker is working intensively with the young adult; he helps him to become independent, not only by providing accommodation, but especially through intensive education in various disciplines, such as financial counselling, career counselling, or the preparation for parenthood and marriage. As was identified in the introduction to this paper, it is practically a necessity, for the work of the social worker, to be familiar with the young adults' ideas on their future parenting. The social worker then has an opportunity to put into practice the young adult's ideas about future parenting and thus contribute to the prevention or elimination of undesirable socio-pathological forms of behaviour, which may occur in the family of the young adult. It is a long-term process, influenced by a number of factors and which we have described in the submitted paper. The absence of similar empirical findings is also evident, due to the fact that research is currently being conducted into the preparation of integration programs for young adults in children's homes, in Slovakia, and the authors were asked - by the organisation Úsmev ako dar (Smile as a gift) - to present the results on the forums of the children's homes' management. 


\section{References}

[1] DVORSKÁ, S. Sociálno-patologické javy u školskej mládeže a ich prevencia. Prevencia a eliminácia sociálno-patologických javov $v$ školskom prostredí, Ružomberok: Katolícka univerzita, 2008, s. 5-7.

[2] FISCHER, S. - ŠKODA, J. Sociální patologie: Analýza příčin a možnosti ovlivňování závažných sociálně patologických javů. Praha: Grada Publishing, a. s., 2007.

[3] HAŠTO, J. Vzt'ahová väzba. Ku koreňom lásky a úzkosti. Trenčín: Vydavatel'stvo F, Pro mente sama s. r. o., 2005.

[4] MATOUŠEK, O. Rodina jako instituce a vztahová sít'. Praha: Sociologické nakladatelství, 1997.

[5] MIKLOŠKO, J. Ohrozená rodina na Slovensku, analýza príčin vyňatia detí z prirodzeného prostredia v rokoch 2006 až 2010. Bratislava: Spoločnost' priateĺov detí z detských domovov Úsmev ako dar, 2011.

[6] NOHEJL, M. Lebenswelt a každodennost v sociologii Alfreda Schütze: pojednání o východiscích fenomenologické sociologie. Praha: Sociologické nakladatelství, 2001.

[7] PAPŠO, P. Vplyv života $v$ detských domovoch na sociálnu adaptáciu mladých dospelých po ukončení náhradnej starostlivosti. Mosty k rodine 2011, Banská Bystrica: SPDDD Úsmev ako dar - pobočka Banská Bystrica, 2011.

[8] RUSNAKOVÁ, M. Vybrané problémy súčasnej rodiny. Kraków, 2008.

[9] VÁGNEROVÁ, M. Vývojová psychologie II. Dospělost a stáří. Praha: Univerzita Karlova v Praze, 2008.

[10] Zákon NR SR č. 305/2005 Z. z. o sociálnoprávnej ochrane detí a o sociálnej kuratele a o zmene a doplnení niektorých zákonov.

[11] ŽARNAY, Š. Praktické problémy so zakladaním rodiny u chlapcov z dysfunkčných rodín: dizertačná práca. Trnava: Trnavská univerzita v Trnave, Fakulta zdravotníctva a sociálnej práce, 2009. 